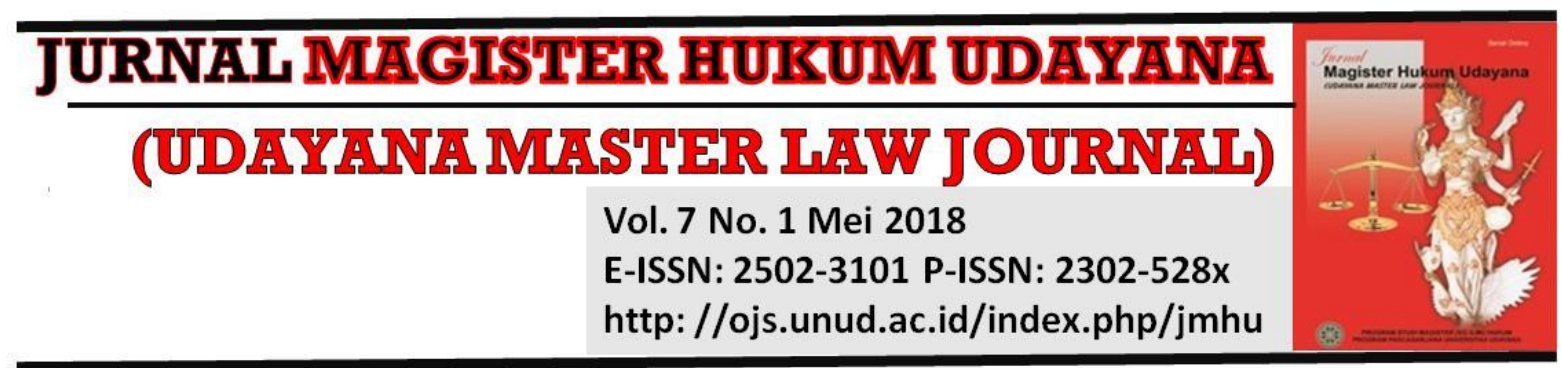

\title{
Legalitas Rekaman Circuit Closed Television (CCTV) Dalam Proses Pembuktian di Persidangan
}

\author{
Ida Bagus Gede Angga Juniarta1
}

${ }^{1}$ BPJS Ketenagakerjaan Cabang Nusa Tenggara Barat

E-mail: idabagusgedeangga1993@gmail.com

\begin{tabular}{l}
\hline Info Artikel \\
\hline Masuk : 3 April 2018 \\
Diterima : 15 Mei 2018 \\
Terbit : 28 Mei 2018 \\
Keywords : \\
Circuit Closed Television \\
(CCTV) Footage, Criminal \\
Procedure Code. \\
\\
\\
\\
Kata kunci: \\
Pembuktian, Rekaman CCTV, \\
Hukum Acara Pidana \\
Corresponding Author: \\
Ida Bagus Gede Angga \\
Juniarta, E-mail: \\
idabagusgedeangga1993@g \\
mail.com \\
DOI : \\
10.24843/JMHU.2018.v07.i01. \\
p04
\end{tabular}

\begin{abstract}
One part of the judicial process is verifying evidence for searching the material truth of case to assist judges in making decisions. One aid that can be used in verification the evidence during the trial is the Information Technology in the form of Circuit Closed Television (CCTV) footage because it is not regulated in the positive Law in Indonesia. Because of that, in this research are used a normative method to answer the problem with the approach of legislation and approach to the concept. The legal arrangement of CCTV footage as evidence in Act No. 8 of 1981 on the Law of Criminal Procedure Code is not exist, because the Criminal Procedure Code are setting a limited valid evidence under the Act, but for the interest of seeking the material truth, then there makes Act No. 11 of 2008 on Information and Electronic Transaction which govern the other evidence in the form of Electronic Information and/or Electronic Records. The strength of evidence from CCTV footage has not been expressly provided in Act No. 11 of 2008 on ITE, so that the strength of evidence is still exempt, which means that the strength of evidence is still based on the judge's conviction.
\end{abstract}


elektronik. Kekuatan pembuktian dari rekaman CCTV belum diatur dalam Undang-Undang Nomor 11 Tahun 2008 tentang ITE, sehingga pembuktiannya masih bersifat bebas, yang artinya kekuatan pembuktian dari alat bukti tersebut masih berdasarkan atas keyakinan hakim.

\section{Pendahuluan}

Penegakan hukum adalah proses memfungsikan norma-norma hukum secara nyata sebagai pedoman perilaku dalam kehidupan bermasyarakat dan bernegara. Proses penegakan hukum pidana dilakukan oleh suatu sistem yang disebut dengan sistem peradilan pidana, yakni mekanisme kerja dalam usaha penanggulangan kejahatan dengan menggunakan dasar pendekatan sistem, yang dalam sistem tersebut ada beberapa substansi bekerja seperti: Kepolisian, Kejaksaan, Pengadilan Negeri, Lembaga Permasyarakatan, dan Advokat. Tujuan dari penegakan hukum pidana yang di dalamnya ditegakkan melalui Hukum Acara Pidana pada hakikatnya memang untuk mencari kebenaran. Menurut $\mathrm{R}$ Soesilo, para penegak hukum dalam sistem peradilan pidana mulai dari polisi, jaksa, advokat, sampai dengan hakim dalam menyelidik, menyidik, menuntut, dan mengadili perkara senantiasa harus mendasar pada kebenaran, harus berdasar pada hal-hal yang sungguh-sungguh terjadi. ${ }^{1}$ Sementara itu, menurut Andi Hamzah tujuan dari hukum pidana yakni untuk mencari dan menemukan kebenaran materiil itu hanya tujuan antara, artinya ada tujuan akhir yaitu yang menjadi tujuan seluruh tertib hukum Indonesia, dalam hal ini mencapai suatu masyarakat yang tertib, tentram, damai, adil, dan sejahtera. ${ }^{2}$ Lebih lanjut, Moch Faisal Salam berpendapat bahwa tujuan hukum acara pidana untuk mencari dan mendapatkan atau setidak-tidaknya mendekati kebenaran materiil, yaitu kebenaran yang selengkap-lengkapnya dari suatu perkara pidana dengan menerapkan ketentuan hukum acara pidana secara jujur dan tepat dengan tujuan untuk mencari siapakah pelaku yang dapat didakwakan melakukan suatu pelanggaran hukum, dan selanjutnya meminta pemeriksaan dan putusan dari pengadilan guna menentukan apakah terbukti telah terjadi suatu tindak pidana dan apakah orang yang didakwa itu dapat dipersalahkan. ${ }^{3}$

Berdasarkan pandangan beberapa sarjana mengenai tujuan hukum acara pidana sebagaimana telah dikemukakan sebelumnya, dapat dikemukakan bahwa tujuan dari hukum acara pidana adalah untuk mencari dan menemukan kebenaran-kebenaran materiil guna menentukan nasib dari terdakwa dalam proses persidangan di pengadilan. Berkaitan dengan tujuan menemukan kebenaran materiil, agenda dalam persidangan yakni proses pembuktian memegang peranan penting. Proses pembuktian ini dimaksudkan untuk mencari kebenaran materiil dari suatu perkara agar hakim dapat mengambil keputusan atas perkara tersebut. Pembuktian dalam perkara pidana berbeda dengan pembuktian dalam perkara perdata. Pembuktian dalam perkara pidana bertujuan untuk mencari kebenaran materiilnya, sedangkan pembuktian dalam perkara perdata bertujuan untuk mencari kebenaran formilnya.

\footnotetext{
1 Sofyan, A. \& Asis, A. (2013). Hukum Acara Pidana Suatu Pengantar, Yogyakarta: PT Rangkan Education. h.11.

2 Ibid.

${ }^{3}$ Ibid.
} 
Pencarian kebenaran materiil dari suatu perkara pidana bukanlah suatu hal yang dapat dengan mudah dilakukan. Hal ini terkait dengan terus berkembangnya modusmodus operandi kejahatan. Oleh karena itu dukungan dari berbagai ilmu pengetahuan diluar ilmu hukum menjadi sangat penting. Salah satu dukungan yang dimaksud adalah teknologi informasi.

Penggunaan teknologi informasi dalam pembuktian acara pidana salah satunya digunakan dalam kasus hukum tewasnya Wayan Mirna Salihin di Cafe Olivier Jakarta pada awal Januari 2016. Kasus pembunuhan Wayan Mirna Salihin dengan tersangka Jessica Kumala Wongso memasuki tahap selanjutnya setelah Kejaksaan Tinggi DKI Jakarta menyatakan berkas perkara Jessica telah lengkap atau P21. Kejati DKI Jakarta menyatakan, berkas perkara Jessica lengkap setelah kepolisian melimpahkan 37 barang bukti, termasuk rekaman Circuit Closed Television (selanjutnya disebut CCTV). ${ }^{4}$

Salah satu barang bukti yakni rekaman CCTV yang dihadirkan oleh Jaksa Penuntut Umum di Pengadilan merupakan barang bukti yang memperlihatkan gerak-gerik dari terdakwa Jessica yang menunjukan adanya indikasi terdakwa memasukan zat sianida ke dalam gelas es kopi vietnam yang telah dipesan sebelumnya. Ahli Telematika dari Kepolisian telah memberikan pendapat ahli tentang rekaman tersebut kepada majelis hakim di muka persidangan. Saat sidang kasus Jessica yang ke - 14 digelar, Ahli hukum pidana Universitas Gadjah Mada, Edward Omar Syarif Hiariej memberikan pendapatnya tentang rekaman CCTV tersebut adalah sebagai alat bukti. ${ }^{5}$ Menurut Andrie W. Setiawan pembuktian rekaman CCTV sebagai alat bukti dalam tindak pidana umum yang diatur dalam KUHP harus didukung dengan alat bukti lain. ${ }^{6}$

Rekaman CCTV merupakan salah satu bentuk dari dokumen elektronik. Hal ini dikarenakan rekaman CCTV yang dimaksud merupakan data yang tersimpan dalam Digital Video Recorder (selanjutnya disebut DVR). DVR ini merekam semua kejadian berdasarkan apa yang terlihat oleh kamera CCTV yang berfungsi sebagai alat pengambil gambar.

Mengacu pada Undang-Undang Nomor 11 Tahun 2008 tentang Informasi dan Transaksi Elektronik (selanjutnya disebut UU ITE), dalam ketentuan Pasal 44 mengatur tentang alat bukti penyidikan, penuntutan, dan pemeriksaan di sidang pengadilan. Pasal 44 huruf b. UU ITE pada intinya mengatur bahwa dimungkinkan adanya alat bukti lain berupa Informasi Elektronik dan/atau Dokumen Elektronik sebagaimana dimaksud dalam Pasal 1 angka 1 dan angka 4 serta Pasal 5 ayat (1), ayat (2), dan ayat (3) U.U. ITE.

Ketentuan Pasal 44 huruf b UU ITE, merujuk pada Pasal 1 angka 1 dan angka 2, serta Pasal 5 ayat (1), ayat (2), dan ayat (3). Pasal 1 angka 1 menjelaskan apa yang dimaksud

\footnotetext{
${ }^{4}$ Nursita Sari. News. http://Megapolitan.kompas.com /read/ 2016/05/28/ 09212231/ babak.baru.jessica.dan.alat.bukti.yang.dipertanyakan, diakses 30 Agustus 2017.

5 Alviansyah Pasaribu, Sidang Jessica, http://www.antaranews.com/berita/580786/sidangjessica-ahli-hukum-pidana-tegaskan-cctv-barangbukti?utm_source=related_news\&utm_medium_campaign=news, diakses 30 Agustus 2017.

6 Ariananda, R. A. (2017). Penggunaan Alat Bukti Rekaman CCTV (Closed Circuit Television) Dalam Proses Peradilan Pidana. Jurnal Poenale, 5:(3). h. 8.
} 
dengan Informasi elektronik dan Pasal 1 angka 4 menjelaskan tentang apa yang dimaksud dengan dokumen elektronik. Selanjutnya dalam Pasal 5 UU ITE mengatur:

(1) Informasi Elektronik dan/atau Dokumen Elektronik dan/atau hasil cetaknya merupakan alat bukti hukum yang sah.

(2) Informasi Elektronik dan/atau Dokumen elektronik dan/atau hasil cetaknya sebagaimana dimaksud pada ayat (1) merupakan perluasan dari alat bukti yang sah sesuai dengan Hukum Acara yang berlaku di Indonesia.

(3) Informasi Elektronik dan/atau Dokumen Elektronik dinyatakan sah apabila menggunakan Sistem Elektronik sesuai dengan ketentuan yang diatur dalam Undang-Undang ini.

Ketentuan Pasal 5 ayat (2) UU ITE tersebut masih menyisakan pertanyaan dalam frasa "perluasan". Kekaburan makna "perluasan" yang dimaksud dalam frasa tersebut yaitu apakah perluasan tersebut ditujukan untuk memperluas macam-macam alat bukti diluar alat bukti dalam Pasal 184 KUHAP atau perluasan terhadap sumber yang dapat dijadikan alat bukti sesuai dengan yang diatur dalam KUHAP. Pasal 184 UndangUndang Nomor 8 Tahun 1981 tentang Hukum Acara Pidana (selanjutnya disebut KUHAP) mengatur alat bukti yang sah dalam Hukum Acara Pidana di Indonesia meliputi: keterangan saksi; keterangan ahli; surat; petunjuk; dan keterangan terdakwa.

Pengelompokan kelima alat bukti itu dikarenakan masing-masing dari alat bukti tersebut memiliki kekuatan pembuktian yang berbeda-berbeda. Sehingga dengan kekaburan norma yang terdapat dalam Pasal 5 angka 2 UU ITE, maka kekuatan pembuktian dalam persidangan yang dimiliki dari dokumen elektronik khususnya rekaman CCTV masih belum jelas dan hal inilah yang menimbulkan banyak perdebatan diantara para ahli hukum. Berdasarkan latar belakang yang telah dikemukakan, maka menarik untuk dikaji lebih lanjut tentang legalitas rekaman Circuit Closed Television (CCTV) sebagai alat bukti di persidangan. Tulisan ini mengelaborasi isu hukum tentang pengaturan rekaman CCTV sebagai alat bukti di persidangan dalam perspektif hukum positif Indonesia, serta kekuatan pembuktian rekaman CCTV dalam persidangan di pengadilan, khususnya dalam dimensi hukum acara pidana.

Studi sebelumnya yang juga mengkaji tentang alat bukti, namun fokusnya berbeda diantaranya: studi yang dilakukan oleh Anak Agung Mirah Endraswari yang mengkaji "Penerapan Beban Pembuktian Terbalik Dalam Perampasan Illicit Enrichment Kaitannya Dengan Hak Asasi Manusia." Kajian tersebut lebih menitik beratkan pada legalitas virtual office yang dipergunakan oleh advokat, dimana salah satu fungsi kantor advokat tersebut adalah untuk mengumpulkan bukti-bukti yang akan dipergunakan di persidangan. ${ }^{7}$ Erna Lisnawati juga mengkaji tentang alat bukti elektronik, khususnya "Keabsahan Alat Bukti Elektronik Pasca Putusan Mahkamah Konstitusi No.20/Puu-Xvi/2016 Dalam Perspektif Criminal Justice System" dengan penekanan pada perbedaan keabsahan penggunaan alat bukti elektronik dalam sistem peradilan pidana (criminal justice system) yang terdapat pada kejahatan konvensional (conventional crime) dengan tindak kejahatan khusus (extra ordinary crime) serta

\footnotetext{
7 Endraswari, A. M. (2016). Penerapan Beban Pembuktian Terbalik Dalam Perampasan Illicit Enrichment Kaitannya Dengan Hak Asasi Manusia. Jurnal Magister Hukum Udayana (Udayana Master Law Journal), 5(2), 392-405.
} 
kedudukan alat bukti elektronik dalam sistem peradilan pidana (criminal justice system) pasca Putusan Mahkamah Konstitusi Nomor 20/PUU-XVI/2016..$^{8}$ Lebih lanjut, I Wayan Ariadi mengelaborasi pengaturan transaksi elektronik di Indonesia, khususnya terkait tanda tangan digital sebagai alat bukti. ${ }^{9}$ Sementara itu dalam tulisan ini focus kajiannya adalah rekaman CCTV sebagai alat bukti.

Penelitian ini bertujuan untuk menemukan kejelasan mengenai pengaturan terhadap rekaman CCTV sebagai alat bukti di dalam proses Acara Pidana yang diatur dalam hukum positif di Indonesia, penelitian ini juga bertujuan untuk menganalisis dan mengidentifikasi kekuatan hukum yang dimiliki rekaman CCTV sebagai salah satu bukti di dalam proses Acara Pidana.

\section{Metode Penelitian}

Metode penelitian hukum menurut William H.Putman dalam bukunya menyatakan, "legal research is a part analysis process. It is that part of legal analysis process that involves finding the law that applies to the legal questions raised by the fact of the client's case". ${ }^{10}$ Kekaburan norma yang ada dalam Pasal 5 angka 2 UU ITE merupakan isu hukum yang dielaborasi dalam studi ini, sehingga jenis metode penelitian yang dipergunakan adalah penelitian hukum normatif. Penelitian ini mempergunakan dua pendekatan yakni pendekatan perundang-undangan, yang dilakukan dengan menggunakan peraturan perundang-undangan yang berlaku sesuai dengan permasalahan yang dibahas, serta pendekatan konsep yang dilakukan dengan melakukan analisis mempergunakan teori, konsep, maupun asas yang berkaitan dengan konsep pembuktian dalam hukum acara pidana.

Bahan hukum yang digunakan dalam penelitian ini adalah bahan hukum primer, bahan hukum sekunder, dan bahan non hukum. Bahan hukum primer yang dimaksud terdiri dari Undang-Undang Nomor 8 Tahun 1981 tentang Hukum Acara Pidana, Undang-Undang Nomor 4 Tahun 2004 tentang Kekuasaan Kehakiman, serta UndangUndang Nomor 11 Tahun 2008 tentang Informasi dan Transaksi Elektronik. Bahan hukum sekunder yang dimaksud terdiri dari buku, jurnal, makalah, atau karya ilmiah hukum lainnya yang terkait dengan permasalahan yang dibahas. Teknik pengumpulan bahan hukum dilakukan dengan meneliti berbagai literatur yang ada kaitannya dengan materi yang akan dibahas dalam penelitian ini, yang kemudian akan dianalisis secara deskriptif analisis.

\section{Hasil dan Pembahasan}

\subsection{Pengaturan Rekaman CCTV Sebagai Alat Bukti dalam Hukum Positif di Indonesia}

Alat bukti memegang peranan penting dalam system peradilan pidana, oleh karena itu perlu untuk diberikan pembatasan dalam pengertian bukti, tanda bukti, membuktikan, dan pembuktian. Pengaturan alat bukti dalam hukum acara pidana umum di Indonesia masih mengacu pada KUHAP. Ketentuan Pasal 184 KUHAP telah

\footnotetext{
${ }^{8}$ Lisnawati, E. (2016). Keabsahan Alat Bukti Elektronik Pasca Putusan Mahkamah Konstitusi No. 20/Puu-Xvi/2016 Dalam Perspektif Criminal Justice System. Jurnal Magister Hukum Udayana (Udayana Master Law Journal) Vol. 5:(4). 677-693.

9 Ariadi, I. W. Bentuk-Bentuk Digital Signature Yang Sah Dalam Transaksi Elektronik Di Indonesia. Jurnal Magister Hukum Udayana (Udayana Master Law Journal), 5(1), 175-183.

${ }^{10}$ Putman, W. H. (2009). Legal Research: Second Edition, United States of America. Delmar. h. 372.
} 
menentukan secara "limitatif" alat bukti yang sah menurut undang-undang. Sehingga dari ketentuan tersebut rekaman CCTV yang merupakan dokumen elektronik belumlah termasuk dalam alat bukti sah sesuai dengan KUHAP. Sehubungan dengan pengaturan bukti elektronik tidak terdapat di dalam KUHAP, hanya diatur dalam undang-undang yang bersifat khusus, oleh karenanya keberadaannya bukti elektronik tersebut dalam penegakan hukum pidana telah menimbulkan kontroversi. ${ }^{11}$ Dalam doktrin hukum acara pidana dikenal beberapa sistem pembuktian yaitu: Sistem keyakinan belaka, Sistem keyakinan dengan alasan logis, Sistem melulu berdasarkan undang-undang, dan sistem menurut Undang-Undang secara terbatas. ${ }^{12}$

Perkembangan jaman saat ini selain memberikan dampak positif, tetapi juga dapat memberikan dampak yang negatif. Salah satu dari dampak negatif tersebut yakni modus maupun tindak kejahatan yang semakin maju dan canggih. Apabila dalam hal pembuktian, alat bukti yang dipergunakan dalam persidangan hanya mengacu pada KUHAP yang telah usang maka hukum acara di Indonesia akan tertinggal jauh, dan makin banyak dari para pelaku kejahatan yang tidak dapat di adili. KUHAP sudah tak sesuai dengan kondisi sekarang sehingga perlu direvisi, dalam KUHAP ada beberapa Pasal tidak relevan dengan keadaan sekarang maka perlu dilakukan revisi. Jadi KUHAP harus disesuaikan dengan keadaan sekarang, karena berdasarkan penjelasan pada Pasal 184 KUHAP hanya mengatur tentang 5 (lima) alat bukti yang sah, dan diluar dari alat-alat bukti tersebut tidak dibenarkan untuk dipergunakan sebagai alat bukti dalam membuktikan kesalahan pelaku tindak pidana. ${ }^{13}$

Dalam hukum acara pidana dikenal istilah perluasan alat bukti yang sah sebagaimana diatur dalam Pasal $184 \mathrm{KUHAP}$, contohnya adalah alat bukti dalam tindak pidana korupsi. Perluasan alat bukti dalam tindak pidana korupsi diatur dalam UndangUndang Nomor 20 Tahun 2001 tentang Perubahan Atas Undang-Undang Nomor 31 Tahun 1999 Tentang Pemberantasan Tindak Pidana Korupsi (selanjutnya disebut UU TIPIKOR) yang telah memberikan makna perluasan alat bukti yang sah yang dapat dipergunakan untuk menegakkan hukum di Indonesia, khususnya dalam rangka pemberantasan korupsi. Perluasan alat bukti tersebut sesuai dengan ketentuan Pasal 26A telah mengatur alat bukti yang sah yang dapat dipergunakan dalam hukum Acara, khususnya untuk tindak pidana korupsi. Ketentuan Pasal 26A mengatur bahwa alat bukti yang sah dalam bentuk petunjuk sebagaimana dimaksud dalam Pasal 188 ayat (2) Undang-Undang Nomor 8 Tahun 1981 tentang Hukum Acara Pidana, khusus untuk tindak pidana korupsi juga dapat diperoleh dari :

a. alat bukti lain yang berupa informasi yang diucapkan, dikirim, diterima, atau disimpan secara elektronik dengan alat optik atau yang serupa dengan itu; dan

b. dokumen, yakni setiap rekaman data atau informasi yang dapat dilihat, dibaca, dan atau didengar yang dapat dikeluarkan dengan atau tanpa bantuan suatu sarana, baik yang tertuang di atas kertas, benda fisik apapun selain kertas,

${ }_{11}$ Ramiyanto, R. (2017). Bukti Elektronik Sebagai Alat Bukti Yang Sah Dalam Hukum Acara Pidana. Jurnal Hukum dan Peradilan, 6(3), 463-484.

${ }^{12}$ Umboh, P. J. (2013). Fungsi dan Manfaat Saksi Ahli Memberikan Keterangan dalam Proses Perkara Pidana. Lex Crimen, 2(2). h. 113.

13 Yenny, A. S., Purba, C. S., \& Lipi, L. (2017). Kedudukan Closed Circuit Television Sebagai Alat Bukti Dalam Perkara Pidana. Jurnal Hukum Media Bhakti, 1(2), 170-181. 
maupun yang terekam secara elektronik, yang berupa tulisan, suara, gambar, peta, rancangan, foto, huruf, tanda, angka, atau perforasi yang memiliki makna.

Hal ini merupakan perluasan dari alat bukti petunjuk yang terdapat dalam UndangUndang Nomor 8 Tahun 1981 Tentang Kitab Undang-Undang Hukum Acara Pidana.

Kedua, perluasan alat bukti lain, dimana mencakup alat bukti baru yang belum dikenal dalam jenis-jenis alat bukti dalam KUHAP. Contohnya dalam tindak pidana pencucian uang. Tindak pidana pencucian uang (selanjutnya disebut TPPU) berbeda dengan tindak pidana lainnya karena dalam TPPU, seseorang dapat dituntut apabila terdapat tindak pidana asal (Predicate Crime) terlebih dahulu dan tindak pidana turunannya (underlying crime) adalah TPPU. Menurut Barda Nawawi Arief, predicate crime atau predicate offence adalah delik-delik yang menghasilkan criminal proceeds atau hasil kejahatan yang kemudian dicuci. ${ }^{14}$ Oleh karena perbedaan tersebut maka tindakan yang dilakukan untuk menduga atau menuntut seseorang sebagai tersangka dalam TPPU memerlukan alat bukti baru di luar dari alat bukti dalam Pasal 184 KUHAP. Alat bukti baru yang belum dikenal dalam jenis-jenis alat bukti sebelumnya yakni Laporan Hasil Analisis PPATK (selanjutnya disebut LHA). LHA merupakan perluasan keberadaan alat bukti dalam TPPU. LHA sebagai alat bukti tidaklah diatur dalam UU TPPU maupun KUHAP, hanya sekedar laporan analisis transaksi keuangan mencurigakan yang dapat dijadikan petunjuk bagi aparat penegak hukum baik kepolisian, kejaksaan, dan pengadilan. Oleh karena itu LHA dapat dikatakan sebagai contoh dari perluasan makna alat bukti baru yang belum dikenal sebelumnya dalam KUHAP

Perluasan alat bukti yang diatur dalam UU Korupsi secara tidak langsung telah mengakomodir rekaman CCTV sebagai salah satu alat bukti yang sah dalam hukum acara di Indonesia. Sayangnya, dalam penerapan ketentuan tersebut tidak bisa diaplikasikan secara penuh dalam hukum acara pidana umum, karena jika kembali mengacu pada sifat yang limitatif dari macam-macam alat bukti dalam Pasal 184 KUHAP, hal ini belumlah memungkinkan. Kendala lainnya adalah pengaturan tentang perluasan alat bukti ini hanya dimasukan ke dalam undang-undang khusus saja.

Selain dalam UU TIPIKOR, pengaturan dokumen elektronik sebagai alat bukti dapat juga dijumpai dalam Undang-Undang Nomor 35 Tahun 2009 tentang Narkotika (selanjutnya disebut UU Narkotika). Ketentuan Pasal 86 mengatur:

(1) Penyidik dapat memperoleh alat bukti selain sebagaimana dimaksud dalam Undang-Undang Hukum Acara Pidana.

(2) Alat bukti sebagaimana dimaksud pada ayat (1) berupa :

a. Informasi yang diucapkan, dikirim, diterima, atau disimpan secara elektronik dengan alat optik atau yang serupa dengan itu; dan

b. data rekaman atau informasi yang dapat dilihat, dibaca, dan/atau didengar, yang dapat dikeluarkan dengan atau tanpa bantuan suatu sarana baik yang tertuang di atas kertas, benda fisik apa pun selain

\footnotetext{
${ }^{14}$ Yusitavana, I. \& et al. (2010). Tindak Pidana Pencucian Uang di Pasar Modal. Jakarta. Ghalia Indonesia. h.54.
} 
kertas maupun yang terekam secara elektronik, termasuk tetapi tidak terbatas pada :

1. tulisan, suara, dan/atau gambar;

2. peta, rancangan, foto atau sejenisnya; atau

3. huruf, tanda, angka, simbol, sandi, atau perforasi yang memiliki makna dapat dipahami oleh orang yang mampu membaca atau memahaminya

Secara eksplisit, terlihat bahwa ciri-ciri yang dimiliki rekaman CCTV sama dengan apa yang dimaksudkan dalam ketentuan Pasal 86 ayat (2) UU Narkotika. Ciri-ciri yang sama dengan apa yang dimaksud dalam ketentuan tersebut, memberikan arti bahwa rekaman CCTV dapat dipergunakan dalam pembuktian tentang tindak pidana narkotika di Indonesia. Aturan terbaru mengenai informasi elektronik serta pengembangannya telah dibentuk dan disahkan oleh pemerintah Indonesia pada saat yang tepat. Tahun 2008 keluarlah Undang-Undang Nomor 11 Tahun 2008 tentang Informasi dan Transaksi Elektronik (selanjutnya disebut UU ITE). UU ITE telah mengakomodir berbagai batasan-batasan pada dunia informasi dan transaksi elektronik, termasuk mengenai alat bukti yang dapat dipergunakan dalam hukum acara pidana di Indonesia.

Terkait alat bukti dalam UU ITE ini diawali dengan pengertian dari apa yang dimaksud dengan informasi elektronik dan dokumen elektronik. Berdasarkan ketentuan Pasal 1 angka 1 UU ITE yang dimaksud dengan informasi elektronik adalah: Informasi elektronik adalah satu atau sekumpulan data elektronik, termasuk tetapi tidak terbatas pada tulisan, suara, gambar, peta, rancangan, foto, electronic data interchange (EDI), surat elektronik (electronic mail), telegram, teleks, telecopy atau sejenisnya, huruf, tanda, angka, kode akses, simbol, atau perforasi yang telah diolah yang memiliki arti atau dapat dipahami oleh orang yang mampu memahaminya

Selanjutnya pengertian dari dokumen elektronik dalam Pasal 1 angka 4 UU ITE menentukan:

Dokumen Elektronik adalah setiap informasi elektronik yang dibuat, diteruskan, dikirimkan, diterima, atau disimpan dalam bentuk analog, digital, elektromagnetik, optikal, atau sejenisnya, yang dapat dilihat, ditampilkan, dan/atau didengar melalui komputer atau sistem elektronik, tetapi tidak terbatas pada tulisan, suara, gambar, peta, rancangan, foto atau sejenisnya, huruf, tanda, angka, kode akses, simbol atau perforasi yang memiliki makna atau arti atau dapat dipahami orang yang mampu memahaminya.

Dengan mencermati pengertian dokumen elektronik berdasarkan Pasal 1 angka 4 UU ITE, maka rekaman CCTV dapat dikategorikan sebagai salah satu dari bentuk dokumen elektronik tersebut, karena memiliki ciri yang sama dengan apa yang telah dijelaskan dalam Pasal 1 angka 4 UU ITE. Melanjutkan pada pengaturan tentang alat bukti dalam hukum acara pidana yang terdapat pada UU ITE, ketentuan Pasal 5 ayat (1) telah memberikan penjelasan bahwa informasi elektronik dan dokumen elektronik merupakan alat bukti hukum yang sah. Bunyi dari ketentuan Pasal 5 ayat (1) yaitu, “Informasi elektronik dan/atau dokumen elektronik dan/atau hasil cetaknya 
merupakan alat bukti hukum yang sah". Penegasan lebih lanjut dari pasal 5 ayat (1) ini dijumpai pada Ketentuan Pasal 5 ayat (2), (3), dan (4).

Telah dipaparkan pada penjelasan sebelumnya tentang eksistensi rekaman CCTV yang merupakan salah satu bentuk dokumen elektronik dalam beberapa hukum positif yang ada di Indonesia yang masih berlaku. Pertama, dalam KUHAP memang tidak mengenal adanya rekaman CCTV ini, karena sifat Pasal 184 KUHAP yang limitatif sehingga membatasi alat bukti dalam persidangan. Perkembangan jaman yang tidak dapat dibendung, menyebabkan dibentuknya aturan di luar KUHAP yang mengakomodir keabsahan alat bukti lain selain yang diatur dalam Pasal 184 KUHAP.

Kedua, UU TIPIKOR dalam ketentuan Pasal 26A telah memberikan jalan untuk memperoleh alat bukti petunjuk lain selain yang diatur dalam Pasal 188 KUHAP. Ketiga, UU Narkotika dalam ketentuan Pasal 86 menyebutkan penyidik dapat memperoleh alat bukti lain selain yang diatur dalam KUHAP. Terakhir yang keempat dalam Pasal 5 UU ITE telah menjelaskan informasi elektronik dan dokumen elektronik dapat dipergunakan sebagai alat bukti. Terlebih lagi dalam ketentuan Pasal 44 UU ITE, alat bukti tersebut dapat dipergunakan untuk penyidikan, penuntutan dan pemeriksaan di sidang pengadilan.

Sesungguhnya terlihat jelas legalitas dari rekaman CCTV sebagai alat bukti di persidangan memang telah diatur dalam UU terkait (UU TIPIKOR, UU Narkotika, UU ITE), tetapi jika berkaca pada teori perjenjangan norma yang dikemukakan oleh Hans Nawiasky, kekuatan UU tersebut masih dibawah KUHAP sebagai ujung tombak aturan hukum acara pidana di Indonesia. Sehingga disini penting untuk dilakukannya pembaharuan terhadap hukum acara pidana Indonesia yang telah usang.

\subsection{Kekuatan Pembuktian Rekaman Circuit Closed Television dalam Persidangan Perkara Pidana}

Kekuatan pembuktian dari rekaman CCTV sebagai alat bukti dalam persidangan tidak terlepas dari pembahasan legalitas cara memperoleh alat bukti elektronik itu diperoleh. Terkait dengan legalitasnya sekarang ini mengacu pada Putusan Mahkamah Konstitusi No.20/PUU-XIV/2016 tanggal 7 September 2016 yang di dalamnya menyatakan bahwa frase informasi elektronik dan/atau data elektronik sebagai alat bukti dilakukan dalam rangka penegakan hukum atas permintaan kepolisian, kejaksaan, dan/atau institusi penegak hukum lainnya yang ditetapkan berdasarkan undang-undang sebagaimana diatur dalam Pasal 31 ayat (3) UU ITE. Jadi ketika rekaman CCTV itu merupakan hasil yang diperoleh dari permintaan penegak hukum, maka itu dapat dikatakan alat bukti atau barang bukti yang sah.

Selain cara memperoleh informasi elektronik tersebut, faktor lain untuk menentukan kekuatan pembuktian dari rekaman CCTV dalam persidangan perkara pidana yakni ketersediaan, keutuhan, keotentikan, kerahasiaan, dan keteraksesan informasi elektronik sesuai dengan Pasal 16 UU ITE. Pasal 6 UU ITE pun mencantumkan bahwa suatu informasi elektronik dan/atau dokumen elektronik dianggap sah sepanjang informasi yang tercantum di dalamnya dapat diakses, ditampilkan, dijamin keutuhannya, dan dapat dipertanggungjawabkan sehingga menerangkan suatu keadaan. Pasal 16 dan Pasal 6 telah memberitahukan bahwa alat bukti elektronik akan mempunyai kekuatan pembuktian yang kuat dan tidak dapat diragukan validitasnya 
dalam persidangan apabila informasi elektronik atau dokumen elektronik tersebut dijamin keutuhan data/informasi elektroniknya serta dapat dipertanggungjawabkan keautentikannya. Yang dimaksud dengan keautentikannya adalah apabila informasi atau data elektronik yang tersimpan dan yang terbaca kembali tidak berubah. Keautentikan menjadi penting untuk melihat seberapa jauh rekaman CCTV dapat dipergunakan sebagai alat bukti yang sah dalam persidangan perkara pidana secara umum di Indonesia.

Pembuktian adalah ketentuan-ketentuan yang berisi penggarisan dan pedoman tentang cara-cara yang benarkan undang-undang, membuktikan kesalahan yang didakwakan kepada terdakwa. Pembuktian merupakan suatu ketentuan yang mengatur alat-alat bukti yang dibenarkan oleh undang-undang, dipergunakan oleh Hakim dalam membuktikan kesalahan yang didakwakan dalam persidangan, dan tidak dibenarkan membuktikan kesalahan terdakwa dengan tanpa alasan yuridis dan berdasar keadilan. ${ }^{15}$ Dalam perkara pidana di Indonesia, system pembuktiannya menganut system pembuktian berdasarkan undang-undang secara negatif, dimana pembuktian harus didasarkan pada undangundang Pasal 183 KUHAP. Berbagai bentuk putusan pengadilan dalam perkara pidana berdasarkan KUHAP adalah putusan pemidanaan, bebas atau lepas dari segala tuntutan hukum bentuk-bentuk putusan pengadilan tersebut harus diucapkan di sidang terbuka untuk umum agar mempunyai kekuatan hukum (Pasal 195 KUHAP). ${ }^{16}$

Beban pembuktian dalam KUHAP dimiliki oleh Jaksa Penuntut Umum, pembuktian terhadap alat bukti sangatlah menentukan dalam persidangan guna meyakinkan hakim bahwa terdakwa bersalah melakukan tindak pidana sebagaimana yang didakwakan dalam surat dakwaan. Adapun pembuktian (law of evidence) dalam perkara pidana meliputi :

a. Alat-alat pembuktian (bewijsmiddelen), adalah alat yang ditentukan oleh undang-undang secara limitatif dan digunakan hakim untuk menggambarkan kembali peristiwa pidana yang telah terjadi lampau dan bersifat mengikat secara hukum;

b. Penguraian pembuktian (bewijsvoering), yaitu cara-cara prosedur menggunakan alat bukti;

c. Kekuatan pembuktian (bewijskracht), yaitu bobot alat-alat bukti, apakah diterima sebagai alat bukti sah, menguatkan keyakinan hakim atau bukan alat bukti yang sah;

d. Dasar pembuktian (bewijsgrond), merupakan alasan dan keadaan dalam menentukan penggunaan alat bukti;

e. Beban pembuktian (bewijlast), adalah pihak yang diwajibkan untuk membuktikan dugaan adanya peristiwa pidana, yaitu jaksa penuntut umum;

f. Objek pembuktian, yaitu hal ikhwal yang dibuktikan surat dakwaan penuntut umum, kecuali segala hal yang secara umum telah diketahui (facta notoir). ${ }^{17}$

15 Harahap, M.Y. (2000). Pembahasan Permasalahn dan Penerapan KUHAP:Pemeriksaan Sidang Pengadila; Banding; Kasasi; dan Peninjauan Kembali. Jakarta. Sinar Grafika. h. 252.

16 Ipakit, R. (2015). Urgensi Pembuktian Alat Bukti dalam Praktek Peradilan Pidana. Lex Crimen, 4(2), h. 88.

17 Widodo, J. P. (2013). Menjadi Hakim Progresif. Bandar Lampung: Indepth Publisihing. h.34. 
Kekuatan pembuktian alat-alat bukti berkaitan dengan pemahaman ketentuan banyaknya alat-alat bukti yang harus ada untuk dapat menjatuhkan pidana (misalkan keterangan terdakwa itu hanya merupakan alat bukti yang sah apabila memenuhi syarat-syarat yang ditentukan dalam Pasal 189 KUHAP). ${ }^{18}$ Perlu untuk diperhatikan dalam membahas kekuatan pembuktian dari rekaman CCTV adalah sistem pembuktian yang di anut oleh Hukum Acara Pidana di Indonesia adalah sistem pembuktian menurut undang-undang secara terbatas (Negatief Wettelijk Bewijstheorie). Menurut sistem ini, dalam hal membuktikan kesalahan terdakwa melakukan tindak pidana yang didakwakan kepadanya, hakim tidak sepenuhnya mengandalkan alat-alat bukti serta dengan cara-cara yang ditentukan oleh undang-undang itu. ${ }^{19}$ Itu tidak cukup, tetapi harus disertai pula keyakinan bahwa terdakwa bersalah melakukan tindak pidana. Keyakinan yang dibentuk ini haruslah didasarkan atas fakta-fakta yang diperoleh dari alat bukti yang ditentukan dalam undang-undang. Makna terbatas dalam sistem ini adalah dalam pembuktian untuk menarik kesimpulan tentang terbuktinya kesalahan terdakwa melakukan tindak pidana disamping dengan menggunakan alat-alat bukti yang sah menurut undang-undang juga dibatasi/diperlukan pula keyakinan hakim. ${ }^{20}$

Dengan memahami bahwa hukum acara pidana di Indonesia menganut sistem pembuktian menurut undang-undang secara terbatas, atau acapkali juga dikenal dengan sebutan menganut system pembuktian menurut undang-undang secara negative, maka terkait alat bukti yang sah dan dapat dipergunakan dalam persidangan merujuk pada KUHAP ketentuan Pasal 184. Alat bukti dan kekuatan pembuktiannya dapat diketahui melalui ketentuan Pasal 184 ayat (1) KUHAP dimana telah menentukan secara "limitatif" alat bukti yang sah, sehingga di luar alat-alat bukti tersebut, tidak dibenarkan dipergunakan untuk membuktikan kesalahan terdakwa. Dampaknya penilaian sebagai alat bukti dan dibenarkan mempunyai "kekuatan pembuktian" hanya terbatas pada alat-alat bukti yang sah menurut Pasal 184 ayat (1).

Rekaman CCTV dalam pembuktian tindak pidana korupsi diakui sebagai alat bukti yang sah selain dari alat bukti keterangan saksi, keterangan terdakwa, dan alat bukti surat yakni sebagai alat bukti petunjuk yang dapat dibentuk melalui bahan-bahan berupa informasi yang diucapkan, dikirim, diterima, ataupun disimpan secara elektronik dengan alat optik atau yang serupa dengan itu. Begitu juga alat bukti petunjuk dapat dibentuk dengan menggunakan bahan dokumen, yakni rekaman data atau informasi yang dapat dilihat, dibaca dan atau didengar yang dapat dikeluarkan dengan atau tanpa bantuan suatu sarana, baik yang tertuang di atas kertas, benda fisik apapun selain kertas, maupun terekam secara elektronik, yang berupa tulisan suara, gambar, peta, rancangan, foto, huruf, tanda, angka, atau perforasi yang memiliki makna. 21

Lain hal saat rekaman CCTV memang tidak diatur dalam KUHAP yang merupakan acuan dalam hukum acara pidana, akan tetapi hal tersebut tidak menutup peluang dari rekaman CCTV di dalam membantu mencari dan membuktikan suatu kebenaran

18 Sofyan, A. Op.cit. h. 232.

19 Chazawi, A. (2008). Hukum Pembuktian Tindak Pidana Korupsi.Bandung. PT. Alumni. h. 28.

20 Ibid.

21 Chazawi, A. Op.cit, h.6 
materiil dari suatu perkara. Peluang yang dimaksud tidak terlepas dari ketentuan Pasal 183 KUHAP yang mengharuskan hakim tidak boleh menjatuhkan pidana kepada seseorang kecuali apabila dengan sekurang-kurangnya dua alat bukti yang sah. Salah satu alat bukti yang sah yakni alat bukti petunjuk, dimana petunjuk itu sendiri adalah perbuatan, kejadian, atau keadaan, yang karena persesuaiannya, baik antara yang satu dengan yang lain, maupun dengan tindak pidana itu sendiri, menandakan bahwa telah terjadi suatu tindak pidana dan siapa pelakunya. Petunjuk yang dimaksud tersebut hanya dapat diperoleh dari keterangan saksi, surat, dan keterangan terdakwa sesuai dengan Pasal 188 ayat (2) KUHAP.

Kaitannya dengan rekaman CCTV yakni rekaman tersebut dapat dijadikan sebagai barang bukti yang menunjukan terjadinya suatu tindak pidana ditambah dengan keterangan saksi maupun keterangan terdakwa sehingga menimbulkan keyakinan hakim akan alat bukti petunjuk dalam suatu perkara pidana. Fungsi ini dikatakan sebagai alat bantu hakim untuk membuat terang suatu tindak pidana ataupun pelaku tindak pidana. Apabila rekaman CCTV tersebut membantu hakim dalam membuat terang suatu tindak pidana maka rekaman CCTV tersebut merupakan perluasan dari alat bukti petunjuk, tetapi apabila rekaman CCTV tersebut membuat terang pelaku tindak pidana maka rekaman CCTV tersebut dapat berdiri sendiri atau alat bukti lain. Walaupun hanya sebatas barang bukti, tetapi dengan rekaman CCTV ini yang kemudian juga ditambah dengan keterangan saksi dan keterangan terdakwa yang dipersesuaikan satu sama lain atas perbuatan yang terjadi, maka ini akan menjadi alat bukti petunjuk yang kuat dalam menemukan kebenaran materiil suatu perkara.

Rekaman CCTV memang bukanlah alat bukti sah yang diatur dalam KUHAP, tetapi rekaman CCTV mempunyai kekuatan pembuktian apabila dalam persidangan dipergunakan sebagai barang bukti yang menunjukan terjadinya suatu perbuatan pidana dengan adanya persesuaian dari keterangan saksi dan keterangan terdakwa ditambah keadaan-keadaan perbuatan itu berhubungan satu sama lain dengan kejahatan yang terjadi. Analisis ini juga diperkokoh dengan pertimbangan hakim pada putusan kasus pembunuhan Wayan Mirna Salihin yang dikeluarkan oleh Pengadilan Negeri Jakarta Pusat Nomor 777/Pid.B/2016/PN.Jkt.Pst dan diperkuat dengan putusan pengadilan Tinggi Jakarta dengan Nomor Putusan 393/PID/2016/PT.DKI. Pertimbangan Majelis Hakim dalam putusan tersebut menyatakan bahwa bukti CCTV dapat menjadi alat bukti yang sah selama berkesesuaian dengan keterangan saksi dan dapat dijadikan alat bukti yang sah, apalagi penggunaan CCTV untuk mengungkap suatu tindak pidana sudah sering dilakukan penegak hukum dan diatur dalam Undang-Undang Nomor 11 Tahun 2008 tentang Informasi dan Transaksi Elektronik.

Berdasarkan analisis dalam pembahasan sebelumnya, frasa "Perluasan" dalam Pasal 5 ayat (2) UU ITE tidak dimaksudkan untuk memperluas macam-macam alat bukti, karena Pasal 184 KUHAP telah mengatur secara limitatif tentang jenis-jenis alat bukti, tetapi "perluasan" yang dimaksudkan yakni memperluas sumber-sumber barang bukti yang dapat dijadikan alat bukti petunjuk di kemudian hari, salah satunya adalah rekaman CCTV. Rekaman CCTV merupakan barang bukti yang terbilang merupakan perluasan dari perkembangan teknologi yang dapat dipadukan dengan keterangan saksi dan keterangan terdakwa untuk menimbulkan alat bukti petunjuk ditambah dengan keyakinan hakim akan kesesuaian rekaman tersebut dengan keadaan-keadaan dalam perbuatan pidana suatu perkara. 


\section{Kesimpulan}

Berdasarkan kajian, elaborasi serta analisis terhadap pengaturan alat bukti serta kekuatan alat bukti rekaman CCTV dalam perkara pidana dapat disimpulkan bahwa pengaturan rekaman CCTV sebagai alat bukti di persidangan dalam Undang-Undang Nomor 8 Tahun 1981 tentang Hukum Acara Pidana belum diatur. Namun, dalam beberapa Undang-Undang Khusus lain terdapat pengaturan mengenai rekaman CCTV yang dapat dipergunakan sebagai alat bukti. Undang-Undang khusus seperti: Ketentuan Pasal 26A Undang-Undang Nomor 20 Tahun 2001 tentang Perubahan Atas Undang-Undang Nomor 31 Tahun 199 Tentang Pemberantasan Tindak Pidana Korupsi, ketentuan Pasal 86 Undang-Undang Tahun 1999 tentang Narkotika, dan ketentuan Pasal 5 ayat 1 Undang-Undang Nomor 11 Tahun 2008 Tentang Informasi dan Transaksi Elektronik. Dalam hukum acara pidana umum yang berlandaskan KUHAP, rekaman CCTV tidak diatur sebagai alat bukti, tetapi hal tersebut tidak membatasi kekuatan pembuktian yang dimiliki dari rekaman CCTV. Kekuatan pembuktian rekaman CCTV saling berkaitan dengan cara memperoleh informasi/data elektronik tersebut. Dalam hal rekaman CCTV yang merupakan barang bukti disesuaikan dengan keterangan saksi dan keterangan terdakwa terkait keadaankeadaan dalam perbuatan pidana, maka dapat diperoleh alat bukti petunjuk yang kuat untuk mencari dan menegaskan kebenaran materiil dari suatu perkara.

Dalam rangka legalitas terkait rekaman CCTV yang notabena merupakan dokumen elektronik, diharapkan ke depannya segera diatur dalam Rancangan KUHAP, sehingga rekaman CCTV mempunyai kekuatan pembuktian yang sah dan jelas dalam semua hukum acara pidana di Indonesia.

\section{Daftar Pustaka}

Buku

Chazawi, A. (2008). Hukum Pembuktian Tindak Pidana Korupsi. Bandung: PT. Alumni.

Harahap, M. Y. (2000). Pembahasan Permasalahan dan Penerapan KUHAP: Pemeriksaan Sidang Pengadilan; Banding; Kasasi; dan Peninjauan Kembali. Jakarta: Sinar Grafika.

Sofyan, A., \& Asis, A. (2013). Hukum Acara Pidana Suatu Pengantar. Yogyakarta: PT Rangkang Education.

Widodo, J. P. (2013). Menjadi Hakim Progresif. Bandar Lampung: Indepth Publisihing.

William, H.P. (2009). Legal Research: Second Edition. USA: Delmar.

Yustiavandana, I., Nefi, A., \& Adiwarman. (2010). Tindak pidana pencucian uang di pasar modal. Jakarta: Ghalia Indonesia.

Jurnal

Ariadi, I. W. Bentuk-Bentuk Digital Signature Yang Sah Dalam Transaksi Elektronik Di Indonesia. Jurnal Magister Hukum Udayana (Udayana Master Law Journal), 5(1), 175-183. https://doi.org/10.24843/JMHU.2016.v05.i01.p16 
Ariananda, R. A. (2017). Penggunaan Alat Bukti Rekaman CCTV (Closed Circuit Television) Dalam Proses Peradilan Pidana. Jurnal Poenale, 5(3).

Endraswari, A. M. (2016). Penerapan Beban Pembuktian Terbalik Dalam Perampasan Illicit Enrichment Kaitannya Dengan Hak Asasi Manusia. Jurnal Magister Hukum Udayana (Udayana Master Law Journal), 5(2), 392-405. https://doi.org/10.24843/JMHU.2016.v05.i02.p13

Ipakit, R. (2015). Urgensi Pembuktian Alat Bukti dalam Praktek Peradilan Pidana. Lex Crimen, 4(2), 88-94.

Lisnawati, E. (2016). Keabsahan Alat Bukti Elektronik Pasca Putusan Mahkamah Konstitusi No. 20/Puu-Xvi/2016 Dalam Prespektif Criminal Justice System. Jurnal Magister Hukum Udayana (Udayana Master Law Journal), 5(4). 677-693. https://doi.org/10.24843/JMHU.2016.v05.i04.p04

Ramiyanto, R. (2017). Bukti Elektronik Sebagai Alat Bukti Yang Sah Dalam Hukum Acara Pidana. Jurnal Hukum dan Peradilan, 6(3), 463-484.

Umboh, P. J. (2013). Fungsi dan Manfaat Saksi Ahli Memberikan Keterangan dalam Proses Perkara Pidana. Lex Crimen, 2(2).

Yenny, A. S., Purba, C. S., \& Lipi, L. (2017). Kedudukan Closed Circuit Television Sebagai Alat Bukti Dalam Perkara Pidana. Jurnal Hukum Media Bhakti, 1(2), 170181.

\section{Peraturan Perundang-Undangan}

Undang - Undang Nomor 8 Tahun 1981 Tentang Hukum Acara Pidana (Lembaran Negara Republik Indonesia Tahun 1981 Nomor 76. Tambahan Lembaran Negara Republik Indonesia Nomor 3258).

Undang - Undang Nomor 20 Tahun 2001 tentang Perubahan Atas Undang-Undang Nomor 31 Tahun 1999 Tentang Pemberantasan Tindak Pidana Korupsi (Lembaran Negara Republik Indonesia Tahun 2001 Nomor 134. Tambahan Lembaran Negara Republik Indonesia Tahun 2001 Nomor 4150).

Undang - Undang Nomor 35 Tahun 2009 Tentang Narkotika (Lembaran Negara Republik Indonesia Tahun 2009 Nomor 143. Tambahan Lembaran Negara Republik Indonesia Tahun 2009 Nomor 5062).

Undang - Undang Nomor 11 Tahun 2008 Tentang Informasi Dan Transaksi Elektronik (Lembara Negara Republik Indonesia Tahun 2008 Nomor 58. Tambahan Lembaran Negara Republik Indonesia Tahun 2008 Nomor 4843).

Undang - Undang Republik Indonesia Nomor 8 Tahun 2010 Tentang Pencegahan Dan Pemberantasan Tindak Pidana Pencucian Uang (Lembaran Negara Republik Indonesia Tahun 2010 Nomor 122. Tambahan Lembaran Negara Republik Indonesia Nomor 516) 


\section{Internet}

Sari, N. News.http://Megapolitan.kompas.com /read/ 2016/05/28/ 09212231/ babak.baru.jessica.dan.alat.bukti.yang.dipertanyakan, diakses 30 Agustus 2017.

Pasaribu, A. Sidang Jessica, http://www.antaranews.com/berita/580786/sidangjessica-ahli-hukum-pidana-tegaskan-cctv-barang-

bukti?utm_source=related_news\&utm_medium_campaign=news, diakses 30 Agustus 2017. 